\title{
The Relationship of the Strategies and Practices of the School Heads and Master Teachers and Teachers' Competencies and Skills in the New Normal
}

\author{
Noruel M. Donato \\ Master Teacher II, Deped Sta Rosa City Laguna, Philippines
}

\begin{abstract}
Monitoring and supervision are essential practices of the school leaders to determine the various aspects of the school's performance as well as teacher's competencies. This study aimed to determine the relationship between the monitoring and supervision strategies and practices of School heads and Master teachers and teachers' competencies and skills in the new normal. The study employed a descriptive-correlational explanatory research design to determine the correlation between the variables. A stratified sampling method was utilized to select the respondents. A total of 385 teachers and 267 school heads and master teachers were the respondents of the study. A survey questionnaire was the primary data gathering instrument. Results of the study show that there is a relationship between the school heads and master teacher's practices and strategies. It also reveals that observance of school heads and master teacher's practices of monitoring and supervision of teachers has a relationship to teachers' competencies and skills. In addition, only staff development influences teachers' competencies and skills. The researcher recommended that the school heads and master teachers may continuously attend professional development activities to further improve some of their strategies and practices in monitoring and supervising teachers and to acquire strategies that are applicable and appropriate to the new normal; the school may offer and conduct activities that may improve and sustain the competencies and skills of teachers especially on the strategies and technology-aided materials and applications that can be used in teaching in distance learning.
\end{abstract}

Keywords: new normal, practices, skills, strategies, teachers' competencies

\author{
This is an open-access article under the CC-BY-NC license.
}

\section{INTRODUCTION}

Education is necessary for a country's development. It provides preparation for the citizens to be valuable participants in the development of the community. It is undeniable that education is one of the most significant accomplishments of an individual. However, the COVID-19 pandemic significantly changes the life of every individual living in a community. It does not only affect human health; it also makes a general shift in the education sector. The students are the ones who are greatly affected by the said health emergency. The process of education was affected because of the current situation (UNESCO, 2020). At this time, the role of teachers is essential. There is a need to adapt to the so-called new normal in education. Emerging to the recent changes in the mode of delivering quality education is a great challenge for teachers. However, teachers are the heart of this education improvement process. Thus, teacher's recognition and collaboration with the monitoring and supervisory strategies and practice, therefore, the methods, processes, forms, or procedures utilized by school heads and master teachers at schools, produce the mechanism for any educational achievement.

According to Peklaj (2015), teacher competency is a factor that impacts students learning. In his study, it shows that teachers' competencies are vital for promoting cognitive, motivational, and social processes. The development of these processes will eventually lead to students' achievement. Teachers must know the concepts of teaching strategies, teaching methods, and activities (classroom management, communication, problem-solving). They must also possess values and attitudes that are appropriate for all learners. All of these 
International Journal of Theory and Application in Elementary and Secondary School Education (IJTAESE), Vol. 3 (2), 125-139

The Relationship of the Strategies and Practices of the School Heads and Master Teachers and Teachers' Competencies and Skills in the New Normal

Noruel M. Donato

have a relationship to student achievement. Similarly, through DepEd Memorandum No. 50 series of 2020, the organization was able to identify and present the priorities for teachers' and school leaders' professional development. It also presented the important competencies that teachers must possess, especially in the new normal. Teachers must apply varied techniques in teaching that will improve the performance of the learners, especially in numeracy and literacy. They must also demonstrate mastery of the content in their field of specialization with integration in other learning areas and must develop activities that improve the higherorder thinking skills of the students. These identified competencies are vital in the implementation of the different learning delivery modalities in the new normal. Moreover, in the study of Hero (2020), he emphasized that in this time of the pandemic, teachers should update themselves about the newest trends in teaching methodologies and attend an educational conference that focuses more on 21st-century teaching methodologies, approaches, and strategies. Teachers should expose and enhance their skills in using technology in teaching for better outcomes for the students. The complex demand for these competencies is in need and a challenge for the public elementary teachers to meet in this new normal.

On the other hand, since teacher competencies are essential, there is a need to properly monitor and supervise teachers. Because of this, improving supervision is one of the major concerns of the Department of Education (Dep Ed). The enactment of RA 9155, otherwise known as 'The Governance of Basic Education Act of 2001', provides the framework for the governance of basic education, which sets the general directions for educational policies and standards. This framework established authority, accountability, and responsibility for achieving higher learning outcomes.

At present, teachers' competencies and skills are based on the competencies stipulated in Philippine Professional Standards for Teachers (PPST), which are related to the presented Competency Model of Thach and Murphy (1995). These competencies are (1) Content Knowledge and Pedagogical skills, (2) Knowledge of Distance Education Field, (3) Organizational Skills, (4) Planning Skills, (5) Communication and Interpersonal Skills, (6) Basic Technology Knowledge, (7) Technology Access Knowledge, (8) Feedback Skills, and (9) Collaboration/Teamwork Skills

Likewise, since one of the concerns of this study is the supervision strategies and practices of school leaders in the new normal, Systems Theory of Management is significant to the current study. According to Chikere and Nwoka (2015), systems theory explains the domination of management during contemporary society. It also clears the functions of multifaceted organizations in modern society; and forecasts that will be a continuous increase in the responsibility of supervision in the intricacy of organizations. It describes the internal and external behavior of an organization. Internally, it provides a clear view about the reasons why and how do its member execute their task as well as their collaborative task. Externally, it can assess the contracts of the organization with the other organizations and institutions. In addition, in the article written by Smith (2009), she stated that in the systems approach, the most important feature of supervision is the connection between supervisor and supervisee, which is commonly concerning and intended at granting control to both members (Holloway, 1995). In this theory, the components of supervision were defined, all associated with the main administrative affiliation.

The statement of theory provided enlightenment to the researcher that there is a need to identify and assess the specific strategies and practices rendered by school leaders to help teachers who experienced the challenges specifically in terms of competencies in their teaching activities because of the COVID-19 pandemic. Teachers' assessment of monitoring and supervision strategies and practices of school leaders is a manifestation of a relationship between them. Insights that will arise from this research are expected to contribute to a better understanding of the importance of proper monitoring and supervision strategies and practices of school leaders. Results of this also helped the researcher to craft a learning and development program appropriate for teachers in the new normal.

\section{Research Questions}

This study generally aimed to determine the relationship between the monitoring and supervision strategies and practices of School heads and Master teachers and teachers' competencies in the new normal. Specifically, this sought answers to the following:

- What is the teachers' mean level of observation on the strategies and practices of the School heads and Master teachers in the monitoring and supervision of teachers in the new normal? 
International Journal of Theory and Application in Elementary and Secondary School Education (IJTAESE), Vol. 3 (2), 125-139

The Relationship of the Strategies and Practices of the School Heads and Master Teachers and Teachers' Competencies and Skills in the New Normal

Noruel M. Donato

- What is the mean level of the Teachers' Competencies and Skills in Distance Education?

- Is there a significant relationship between teachers' mean level of observance of school heads and master teachers' practices of monitoring and supervision and teachers' competencies and skills?

- Do the teachers' mean level of observance of School Heads and Master Teacher's Practices singly or in combination influence teachers' competencies and skills?

- What Learning and Development Programs for Teachers can be offered to further develop teachers' competencies and skills in the new normal?

\section{Hypotheses}

The researcher was guided by the following hypotheses. The hypotheses of the study are presented in the following null form (HO):

- There is no significant relationship between teachers' mean level of observance of school heads and master teachers' practices of monitoring and supervision and teachers' competencies and skills.

- The teachers' mean level of observance of School Heads and Master Teacher's Practices singly or in combination do not influence teachers' competencies and skills.

\section{LITERATURE REVIEW}

\section{Strategies and Practice in Monitoring and Supervision}

According to Etor (2020), there are arguments between teachers, school leaders, and legislators regarding how instructional supervision is implemented and its ultimate purpose. Also, based on Iroegbu \& Eyo (2016), in the absence of the school head, there is always a person who will assume the role and functions of the principal. The efficiency of the institution mainly depends on the capacity of the school to perform supervisory activities. It is important to have a clear instructional goal and work collaboratively for the improvement of teaching and learning (Smylie, 2020)

Instructional supervision involves a professional continuous, and cooperative process. Its main purpose is to improve the instruction of teachers. It requires management, support, expressing ideas, assistance, or innovation to improve teacher's ability in handling different learning situations. It will also improve the quality of learning in the schools. It may depend on the collaboration among its members and the school leaders. These leaders must possess a greater understanding and knowledge regarding the school environment. They must facilitate collaboration to create improvement for the school and its professional learning community.

According to Glickman (2020), developmental supervision is another supervisory approach that can help teachers in improving their instructional competencies. Educational experts introduced the term differentiated instruction. In this kind of supervision, the teachers have an opportunity as to how they want to be supervised and evaluated. Some of them assumed that majority of the teachers would be involved in teacher assessment, staff development, and casual observations. These processes are very necessary for improving instruction no matter what their experiences or competencies. Experience or competence. There is a need for a harmonious setting to have successfully differentiated supervision. It nurtures a collaborative relationship anchored on mutual aid and participation.

In addition, according to Sullivan and Glanz (2020) and Zepeda (2020), there are different changes in the term supervision. The concept of clinical supervision has constantly encountered numerous criticisms. As time passed by, there were transitions in the idea of clinical supervision. It was due to modern social issues, scholastic responsibility, and electoral mandates. Experts try to provide a clear view regarding the changes in the supervisory processes and produce an impression on the challenges correlated with instructional supervision. Reflection and knowledge creation are more collaborative foundational learning concepts than traditional and teacher-centered learning.

The presented supervision styles were presented already different times for it is said to improve the supervisory practices of every school leader. Aseltine et al. (2016) named this as performance-based supervision and evaluation model (PBSE). They truly believe that the practices coupled with this model 
International Journal of Theory and Application in Elementary and Secondary School Education (IJTAESE), Vol. 3 (2), 125-139 The Relationship of the Strategies and Practices of the School Heads and Master Teachers and Teachers' Competencies and Skills in the New Normal

Noruel M. Donato

can help re-professionalize teachers' performance, which will enable them to acquire effective strategies that may help improve the critical and instructional ability of schools. It was established and initially executed in their home state of Connecticut, where it showed a useful way of improving instruction and student learning and enhancing professional culture.

Based on the study conducted by Lopez (2016) on classroom supervisory practices in the Philippines, the participants agreed that the principal sometimes records familiar words, phrases, and sentences for the teacher to provide the teacher with more accurate feedback. Results of her study also revealed that she sometimes records the series of questions asked by the teacher to improve the teacher's question techniques and occasionally records directions given by the teacher in the course of the lesson. To say that supervisors are providing their assistance to the teacher in the classroom is to explain that the observation records serve as a valuable and informative picture of follow-up work, which can be used to monitor suggestions. Regardless of the type of recording method employed, it is essential to capture as much of the visit as possible within a minimum amount of time and energy. It is essential to do this for the teacher, and the learner can benefit from the information in the classroom.

\section{Teachers' Competencies and Skills in the New Normal}

Teachers play a significant role in the so-called New Normal in Education. The role is broader as compared to the typical classroom setup. Even though they are working at home in the new normal, they must always be available for queries from the students and parents. Tarek (2016) emphasized since distance learning entails greater responsibility because it requires an interaction between the teachers and students. Teachers must always consider the individual needs of the learners. Teachers may provide collaborative virtual learning activities to motivate learners. They must demonstrate creativity in whatever they are doing since it has an impact on the learners. It enables the learners to participate in virtual learning activities and engage them in deeper learning to meet the desired learning outcomes (Tuscano, 2020).

Saxena \& Saxena (2020) constructed a framework highlighting the role of teachers in times of pandemics. It also emphasizes the levels of teaching for effective learning. As the learners have distinct personalities and learning styles, teachers must develop and implement varied teaching strategies appropriate to learners' abilities. Aside from the different teaching strategies, in the study of Warden, Stanworth, Ren \& Warden (2013), they presented that the primary source of the problem in synchronous learning is behavior. Thus, teachers must still employ effective virtual classroom management. It is a measure of success in the new normal of teaching.

However, Bower, Dalgarno \& Kennedy (2013) stipulated that the main struggle in blended learning was communication and split attention. Looking at the present situation worldwide, teachers portray a very vital role in lessening the anxiety of the learners due to this pandemic. Educating learners in this time of pandemic is not easy. That is why teachers must be trained appropriately to facilitate teaching in the new normal. There is a need for certification and training programs utilizing different online platforms. Teachers must also be given complete and appropriate instructional materials, learning modules, and other resources needed in teaching in the new normal. Teachers are the most important in classroom teaching. They play an essential role in the development of learners. Thus, the responsibility to mold and shape pupils' abilities lies in their hands. For teachers to perform at their best and to improve their teaching competencies, they must improve their efficacy. Developed teaching efficacy in this time of pandemic is very important. The personal belief of teachers regarding their teaching capabilities contributes to their self-efficacy. These beliefs are related to their behavior demonstrated in the classroom. It established a difference in terms of types of teaching strategies and methodologies.

As a support to the statement mentioned, Prytula and Weiman (2012) mentioned that a teacher understands their personality. They also recognize their strengths and weaknesses. It is highly associated with the practices and traditions of the school. The identity of teachers will be known more if they will examine their learning and professional development according to the elements of teacher 
International Journal of Theory and Application in Elementary and Secondary School Education (IJTAESE), Vol. 3 (2), 125-139

The Relationship of the Strategies and Practices of the School Heads and Master Teachers and Teachers' Competencies and Skills in the New Normal

Noruel M. Donato

identity and comprehend how the different factors such as the environments, forms, and works habits affected the progress of schools. The study of Mojavezi and Tamiz (2012) concluded that teacher selfefficacy could affect students' enthusiasm and success in different settings; thus, it is not context-bound. It is also essential that educational contexts and school administrators provide clear opportunities to improve the efficacy of the teachers since it can develop motivations among learners and eventually improve their academic performance.

\section{Learning and Development Programs for Teachers}

According to Ertmer et al. (2012), inadequate professional development and training are the most prominent reasons why there is a failure in the application of technology in the classroom. The study of Johnson et al. (2016) stated that newly hired teachers must still undergo professional training to maintain their skills even though they are already equipped with current classroom technology. They also stated that necessary resources are needed in providing specialized training for teachers. The specific kind of preparation available to teachers is an essential consideration.

They also added that even there are many available technologies appropriate for teaching. Teachers must be knowledgeable and confident in using these technologies. It is a fact that many teachers grew up without access to different kinds of technology. At present, these kinds of teachers will be intimidated by their learners because they are advanced in terms of technological knowledge.

Similarly, the study of Johnson et al. (2016) regarding the challenges and support to teachers' utilization of technology in teaching presented recommendations to improve using technologies in the classroom. Some of the recommendations include looking for assistance from the ISTE to find useful professional development platforms. Capacitate the ability of school leaders in the provision of professional education. Appeal for training regarding the new scholastic package adopted and provide enough and suited technological, organizational, and peer assistance to teachers.

Also, in the study of Ghavifekr and Rosdy (2015), it was also discovered that professional development training programs for teachers performed a vital function in improving students' quality of learning. Other researchers may consider studying the other concepts of ICT integration, especially from a management perspective regarding strategic planning and policymaking. Similarly, Burns (2015) stated that there must be a guide on how a teacher will utilize technology in teaching. Constant followup and support are needed so that teachers can plan for activities related to technology.

Professional technology advancement should destress the significance of teachers' expertise with software and hardware and emphasize teachers' security and trust in utilizing computers. She emphasized that encouraging teachers to imagine themselves as project managers of a particular activity is very useful. Moreover, careful planning is also needed when teachers want to use technology in their classrooms. It only implies that integrating technology in the classroom needs a participative action of teachers, scholastic technology specialists, and school leaders; that is why assisting teachers is essential, most specifically this time of the pandemic.

Likewise, beginning teachers are the most vulnerable to different challenges in education. For this reason, they are the ones who have low self-efficacy and must need to be improved. Older teachers must foster a positive attitude and must encourage them to develop themselves. Also, the results of this study indicated a positive correlation between teacher self-efficacy and students' motivation and achievement. For Mendoza, as cited by Canon (2015), a teacher plays an essential function in guiding and directing learning outcomes. Teachers should determine ways on understanding the clients. It is not sufficient that he knows the learners' role. He should also know his role in the group, plus the factors behind his function and reaction to certain stimuli. He must instill that driving desire for continuous development of his abilities.

Because of the struggles brought by the COVID-19 pandemic, the Department of Education is pursuing different measures to provide quality education. Enclosure to DepEd Order No. 012, s. 2020 is the Learning Continuity Plan which will be used during the time of the pandemic. This LCP aims to ensure 
International Journal of Theory and Application in Elementary and Secondary School Education (IJTAESE), Vol. 3 (2), 125-139

The Relationship of the Strategies and Practices of the School Heads and Master Teachers and Teachers' Competencies and Skills in the New Normal

Noruel M. Donato

the continuity of the delivery of learning by offering different learning delivery modalities. Through the National Educators Academy of the Philippines (NEAP), the Department of Education commits to providing and supporting professional development for teachers and school leaders. Also, through DepEd Memorandum No. 50 series of 2020, the organization was able to identify and present the different priorities for the professional development of teachers and school leaders. It will enable teachers to improve their teaching competencies.

\section{RESEARCH METHOD}

The descriptive-correlational explanatory research design was employed in this study to determine the correlation between the variables using statistical analyses such as weighted mean, Pearson $r$, and Hierarchical stepwise multiple regression analysis. Weighted mean was used to determine the teacher's mean level of observance of School Heads and Master Teacher's strategies and practices in monitoring and supervision of teachers in the new normal as well as teachers' competencies and skills. Pearson $r$ was employed to establish the relationship between the assessed level of observance of school heads and master teachers' monitoring and supervision strategies and the assessed level of observance of school heads and master teachers' monitoring and supervision. The relationship between teachers' competencies in the new normal and assessed level of observance of school heads and master teachers' monitoring and supervision practices, the Pearson product-moment correlation was employed. Hierarchical stepwise multiple regression analysis was used to measure the influence of School Heads and Master Teachers' Supervision and Monitoring Practices and Teachers' Competencies in the new normal. It is utilized in order to calculate the contributions of predictors above and beyond previously entered predictors. This is also a sequential process that involves the entry of predictor variables into the analysis in steps (Lewis, 2007). It is also typically added to the researcher's understanding of the phenomena being studied since it requires thoughtful input to the researcher in determining the order of entry of Independent Variables and yields successive tests of the validity of the hypotheses which determine that order.

The respondents of the study were composed of 108 public elementary schools, of which were 385 teacher respondents and 267 Elementary School Heads and Master Teachers/ Head Teachers in the city schools' divisions of Biñan, Cabuyao, Calamba, and Santa Rosa. The sample size was calculated using Cochran's Formula at $95 \%$ confidence level with a margin of error equal to (0.05). After determining the number of schools per division, stratified sampling was utilized to determine the number of respondents.

The study utilized two survey questionnaires. The first instrument employed was a two-part survey questionnaire. It was designed to determine the mean level of observation on the strategies and practices of the School heads and Master teachers in the monitoring and supervision of teachers in the new normal. The domains that were assessed include the following strategies; Assisting Teachers in the Use of Technology in the Teaching Process, Conducting Virtual Observation, Conducting Online SLAC Session, Online Monitoring of Teachers' Instruction and Teaching Delivery; while the domains that were assessed regarding their practices include; Instructional Supervision, Staff Development, Curriculum Development, and Mentoring and Instructional Support for Teachers.

The second instrument is designed to determine the level of teachers' competencies and skills. The domains included were Content Knowledge and Pedagogical Skills, Knowledge of Distance Education Field, Organizational Skills, Planning skills, Communication and Interpersonal Skills, Basic Technology Knowledge, Technology Access Knowledge, Feedback skills, and Collaboration/Teamwork skills.

These survey questionnaires were answered through Google form with the respondents' written consent that was approved by the LSPU ethics committee and validated by experts. Proper treatment and handling of the documents were considered and handled appropriately. The researcher assured the confidentiality of the answer of the respondents.

\section{FINDINGS AND DISCUSSION}

This chapter presents the findings on the assessments of the observation on the practices and implementation of the School heads and Master teachers in the monitoring and supervision of teachers and teachers' competencies in the new normal. It also reports the identified relationship between the monitoring and supervision strategies and practices of School heads and Master teachers and teachers' competencies. 
International Journal of Theory and Application in Elementary and Secondary School Education (IJTAESE), Vol. 3 (2), 125-139

The Relationship of the Strategies and Practices of the School Heads and Master Teachers and Teachers' Competencies and Skills in the New Normal

Noruel M. Donato

Table 1 reveals the assessments of teachers on school heads and master teachers/head teachers' observance of implementing strategies in monitoring and supervision of teachers.

The presented data shows that in most of the indicative statements, the school head and master teachers/head teachers' implementation of strategies in monitoring and supervision of teachers in the new normal is Highly Observed. The teachers perceived that school heads and master teachers were doing their part in assisting teachers in the use of technology. Being the school leaders, they are initiating activities that motivate teachers to utilize technology to be able to deliver quality learning for the learners. They also encourage the teachers to be innovative. The shift from the face-to-face delivery of learning to online and modular distance learning requires the teachers to be knowledgeable in the use of the technology. Because of this, assistance from school leaders is highly valuable.

It also implies that school leaders were also considerate about the struggle experienced by the teachers in the new normal. Even though they advise the teachers to employ active learning in teaching, they are not pressuring the teachers. It is a good sign that they are employing appreciative inquiry in the conduct of virtual observation. The most recent work by Murphy (2013), which highlights various aspects of classroom observation, served as the support of the study results. Also, based on the study of Iroegbu and Eyo (2016), classroom observation offers an opportunity for supervisors to assess teachers' styles, their classroom management skills, and various aspects of teaching that are difficult to attain through other forms of evaluation. Moreover, it allows teachers to receive constructive feedback on their teaching techniques and methods to improve them further. In a nutshell, it is one of the most common ways of reflecting on pedagogical practices (Farrell, 2020), which can help teachers evaluate their strengths and weaknesses.

Table 1. Teacher's Mean Level of Observation on Strategies Implemented by SH and MT

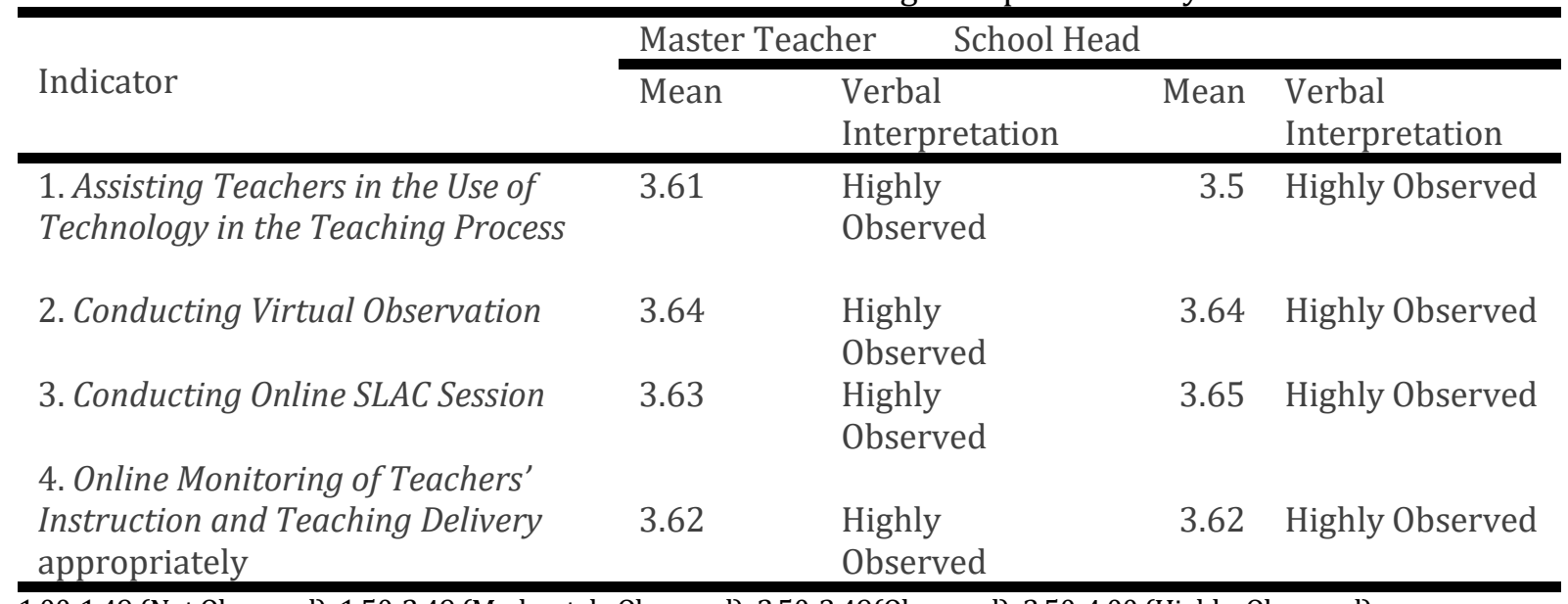

1.00-1.49 (Not Observed); 1.50-2.49 (Moderately Observed); 2.50-3.49(Observed); 3.50-4.00 (Highly Observed)

Likewise, it denotes that school heads and master teachers follow the same routine, framework, and strategies to conduct school learning action cells. The level of observations provides a clear manifestation that they are knowledgeable in providing and enhancing teachers' knowledge, skills, and attitudes through different learning development activities and programs. This claim was supported by the study conducted by Gumban (2019). She found that teachers' work performance is significantly correlated to the implementation of school learning action cells. It indicates that teachers become more effective with the implementation of the school learning action cell. Binauhan (2019) reiterates that if the group (LAC) facilitator consistently undertakes the functions mentioned above, they eventually learn and exhibit these skills themselves. It also implies that school leaders were offering ways to improve the teachers' professional learning since it is indispensable at this pandemic. It may also mean that they believe that the teacher's performance in the new standard will be improved through the school learning action cell.

It infers that school heads and master teachers have provided a toolkit that can be used to monitor teachers' instruction and teaching delivery since both are raters in the classroom observation of teachers. It 
International Journal of Theory and Application in Elementary and Secondary School Education (IJTAESE), Vol. 3 (2), 125-139

The Relationship of the Strategies and Practices of the School Heads and Master Teachers and Teachers' Competencies and Skills in the New Normal

Noruel M. Donato

entails as well that at present, despite the limitations in the face-to-face monitoring due to the COVID-19 pandemic, still, the school leaders were making different strategies to be able to monitor teacher's instruction and teaching delivery. It is a good indication that they are ensuring that despite the hindrances brought by this pandemic, still teachers' instruction and the delivery of learning will be of quality. According to Laska (2016), school leaders' most crucial responsibilities are monitoring and evaluating teachers. Through observation and analysis, the school leaders of the school tend to know what is happening in the school

Table 2 shows the results and analyses on the assessments of the teacher respondents on the observance of the practices of School Heads and Master Teachers in monitoring and supervision of teachers in the new normal.

Table 2. Teacher's Mean Level of Observation on Practices Implemented by SH and MT

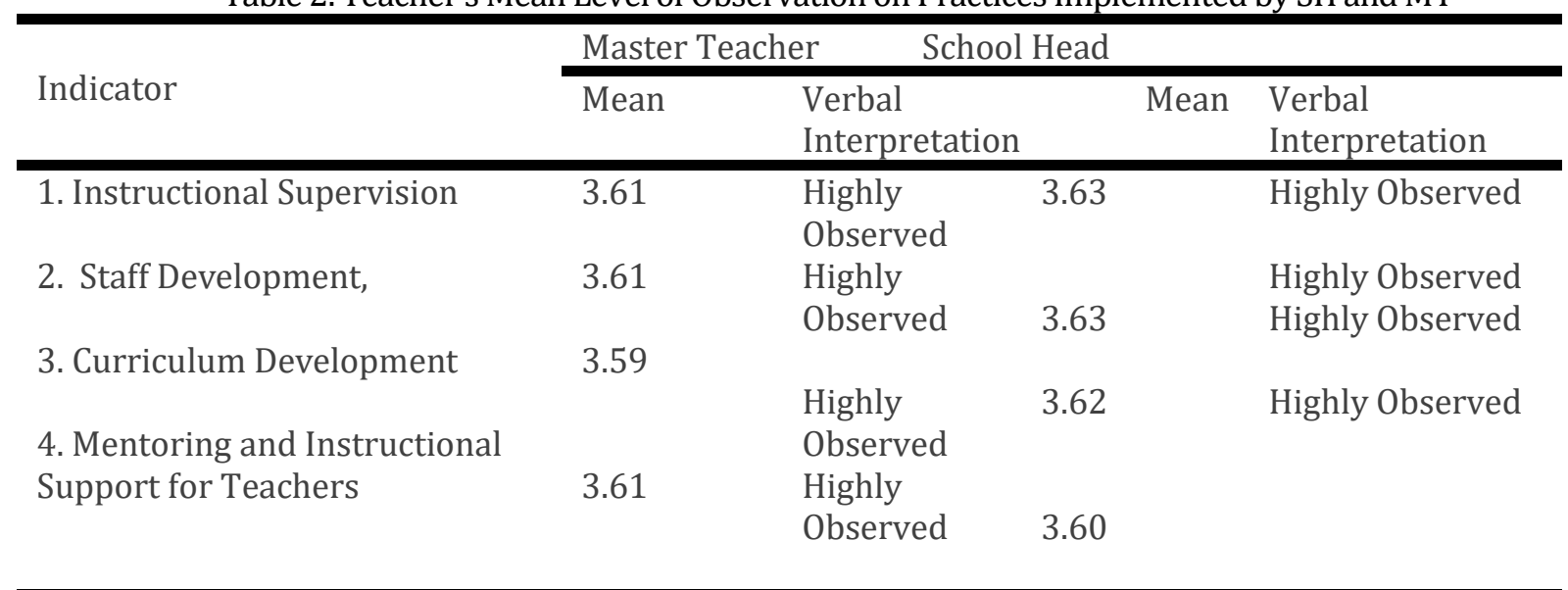

1.00-1.49 (Not Observed); 1.50-2.49 (Moderately Observed); 2.50-3.49(Observed); 3.50-4.00 (Highly Observed)

Table 2 indicates the teacher's mean level of observation on practices implemented by school heads and master reveals that both the school heads' and master teachers' practices are Highly Observed in all the given indicators. The effectiveness of the school mainly depends on the ability of the school to perform supervisory activities. It is important to have a clear instructional goal and work collaboratively for the improvement of teaching and learning (Smylie, 2020).

It also implies that master teachers and school heads are working hand-in-hand, and they have the same practices towards staff development. It also entails that they are regularly having conferences and staff meetings. It is an exemplary manifestation of their consistency in monitoring teachers. They may be doing this practice to determine the concerns of the teachers immediately. According to Ekyaw (2014), to improve the instruction of teachers, the school leaders must plan for the effective delivery of staff development programs. They must ensure that these efforts will have an allotted budget and enough time for planning and implementation of the program.

Likewise, the data shows that both school heads and master teachers are key players in the development of curriculum since they are the ones who serve as the frontliners on its implementation, monitoring, assessment, and evaluation, which make them familiarize with the different processes, frameworks, and principles about the curriculum. This claim is supported by the study of Ornstein \& Hunkins (2012). According to them, the curriculum development process is usually carried out by educators in committees working together. Also, Bas and Senturk stipulated that for the curriculum development to be successful and effective, all groups (i.e., teachers, parents, students, administrators, and inspectors) affected by the current curriculum need to be involved. Therefore, instructional leaders such as school heads and master teachers must spend more time developing knowledge and implementing the curriculum and instruction and assessment rather than sticking to the traditional and conventional way of doing it.

Results also indicate that both school heads and master teachers serve as a coach and mentors to the teachers regarding instructions and delivery. The coaching and mentoring to the teachers are one of their key result areas and indicators. According to Dolorosa (2020), instructional leaders and supervisors are tasked to 
International Journal of Theory and Application in Elementary and Secondary School Education (IJTAESE), Vol. 3 (2), 125-139

The Relationship of the Strategies and Practices of the School Heads and Master Teachers and Teachers' Competencies and Skills in the New Normal

Noruel M. Donato

perform supervisory practices. Through this, the teachers were able to obtain support for their professional improvement.

It shows that in all the indicators, the teachers are Highly Proficient. It implies that teachers are competent and possess the appropriate skills in dealing with the new normal in education. They are also equipped with the needed skills and competencies to handle classes in the new standard set-up wherein different learning modalities provide continuous essential education services to the students. The study of Puteh (2016) supported the result of this study regarding the importance of content knowledge and pedagogical skills. According to him, it plays an essential role in classroom instructions. Table 3 presents the mean level of teachers' competencies and skills in distance education.

Table 3. Mean Level of Teachers Competencies and Skills in Distance Education

\begin{tabular}{|c|c|c|c|}
\hline Indicator & Mean & SD & Verbal Interpretation \\
\hline 1. Content Knowledge and Pedagogical Skills & 3.61 & .50 & Highly Proficient \\
\hline 2. Knowledge of Distance Education Field & 3.57 & .49 & Highly Proficient \\
\hline 3. Organizational Skills & 3.60 & .49 & Highly Proficient \\
\hline 4. Planning skills & 3.59 & .49 & Highly Proficient \\
\hline 5. Communication and Interpersonal Skill & 3.66 & .47 & Highly Proficient \\
\hline 6. Basic Technology Knowledge & 3.55 & .49 & Highly Proficient \\
\hline 7. Technology Access Knowledge & 3.58 & .49 & Highly Proficient \\
\hline 8. Feedback skills & 3.63 & .48 & Highly Proficient \\
\hline 9. Collaboration/Teamwork skills & 3.65 & .47 & Highly Proficient \\
\hline
\end{tabular}

1.00-1.49 (Below Basic); 1.50-2.49 (Basic); 2.50-3.49 (Proficient); 3.50-4.00 (Highly Proficient)

Likewise, the study of Ferreira, Behrens, Torres, and Marriott (2018) stated that an online education teacher must explore and use all of the technological possibilities related to teaching and learning as well as they should have a clear understanding of the knowledge embedded in this network. Therefore, when using technological resources, the teacher must clearly understand that these resources are designed to foster learning in the same way that ICT fosters socialization and collaboration in knowledge production.

At present, the challenge posed by this pandemic shows that teachers may make fun-filled activities to motivate the learners to attend online classes and be participative and even be interested in modular distance learning. Teachers may utilize different online applications to be able to sustain the interest of the learners. This was supported by the study of Litman (2020) stated in the Victoria Transport Policy Institute. According to him, planning refers to a person's strategy in preparing how an activity will be conducted. It occurs at different levels, and it is an example of complex decision-making. His statement is a clear manifestation that planning skill is essential for teachers.

Moreover, the result reveals that teachers are adaptable to the changes brought by the pandemic. Teachers provided different options to both the students and parents as to how they will help each other in monitoring the achievement and progress of the students and the platforms that they will use to have open communication with them. They are also introducing new applications to continuously reach students and parents so that they can address the needs, answer their queries, and provide feedback regarding the status of each student. 
International Journal of Theory and Application in Elementary and Secondary School Education (IJTAESE), Vol. 3 (2), 125-139

The Relationship of the Strategies and Practices of the School Heads and Master Teachers and Teachers' Competencies and Skills in the New Normal

Noruel M. Donato

Such findings are also seen in a recent report in the literature. According to Ferreira, Behrens, Torres, and Marriott (2018), an online education teacher must explore and use all the technological possibilities related to teaching and learning and have a clear understanding of the knowledge embedded in this network. Table 4 shows the test of the relationship between teachers' observance of school heads and master teachers' practices of monitoring and supervision and teachers' competencies.

Table 4. Correlation Matrix for School Head/Master Teachers' Practices and Teacher's Competencies

\begin{tabular}{|c|c|c|c|c|}
\hline \multirow[b]{2}{*}{ Teacher's Competencies } & \multicolumn{4}{|c|}{ School Head/Master Teacher Practices } \\
\hline & $\begin{array}{l}\text { Instructional } \\
\text { Supervision }\end{array}$ & $\begin{array}{c}\text { Staff } \\
\text { Development }\end{array}$ & $\begin{array}{l}\text { Curriculum } \\
\text { Development }\end{array}$ & $\begin{array}{l}\text { Mentoring \& } \\
\text { Instructional } \\
\text { Support }\end{array}$ \\
\hline $\begin{array}{l}\text { Content Knowledge and } \\
\text { Pedagogical Skills }\end{array}$ & $.133^{*}$ & .045 & -.105 & $.194^{* *}$ \\
\hline $\begin{array}{l}\text { Knowledge of Distance } \\
\text { Education Field }\end{array}$ & .053 & -.035 & $-.122 *$ & .006 \\
\hline Organizational Skills & .031 & .019 & .089 & -.007 \\
\hline Planning Skills & $.187 * *$ & .022 & $.134 *$ & .044 \\
\hline $\begin{array}{l}\text { Communication and } \\
\text { Interpersonal Skills }\end{array}$ & .005 & .020 & .061 & .001 \\
\hline $\begin{array}{l}\text { Basic Technology } \\
\text { Knowledge }\end{array}$ & .036 & .009 & -.081 & .006 \\
\hline $\begin{array}{l}\text { Technology Access } \\
\text { Knowledge }\end{array}$ & .040 & -.025 & .084 & .052 \\
\hline Feedback Skills & .007 & .007 & .044 & .033 \\
\hline $\begin{array}{l}\text { Collaboration/Teamwork } \\
\text { Skills }\end{array}$ & .007 & $.214^{* *}$ & -.039 & .031 \\
\hline
\end{tabular}

**significant at .01 level

*significant at .05 level

Findings show that school heads/master teachers' practices in terms of instructional supervision have a significant relationship to content knowledge and pedagogical skills $(\mathrm{r}=0.133)$ at a 0.05 level of significance. It also has a highly significant relationship to planning skills ( $r=.187$ ) at a 0.01 level of significance. The remaining indicators of teacher competencies have no significant relationship to the instructional supervision of school heads and master teachers.

It implies that effective implementation of instructional supervision practices can improve the teacher's competencies. School heads and master teachers, as instructional leaders, should properly execute these instructional supervision practices to motivate teachers to perform at their best. There must be guidance, assistance, sharing of ideas, facilitation, or creation from the school leaders to help teachers improve the learning situation and quality of learning in the schools.

On the other hand, staff development as a practice of the school heads/master teachers has a highly significant relationship on collaboration/teamwork skills ( $\mathrm{r}=.214)$ at 0.01 level of significance. In contrast, all other indicators have no significant relationship to the staff development of school heads and master teachers. 
It implies that the practices of SH/MT on staff development enable the teachers to promote collaboration and teamwork among them. It means that in this time of the pandemic, there is a need for the school leaders to appropriately guide the teachers to help them overcome the challenges brought by COVID19 through collaborative efforts. It also implies that reasonable staff development practices may encourage the teachers to participate in whatever programs the school will implement in this new normal.

Furthermore, in terms of curriculum development as a practice of the school heads/master teachers, it has a significant negative relationship on knowledge of distance education field $(\mathrm{r}=-.122)$ and a significant positive relationship on planning skills $(\mathrm{r}=134)$ at 0.05 level of significance. In contrast, the remaining indicators have no significant relationship to curriculum development.

It implies that school leaders' curriculum development practices may improve teachers' competencies in the new normal. If the $\mathrm{SH} / \mathrm{MT}$ involved the teachers in developing the curriculum, it is more likely that they will be abreast of how the curriculum should be implemented in the new normal. However, the study results also imply that curriculum development practices undesirably affect teachers' knowledge in distance education. It means that when SH/MT implements activities on curriculum development, it is most likely that teachers will have lesser knowledge in distance education. It may be because, at present, teachers are still adjusting to the so-called new normal in education. The more changes are implemented in our curriculum, the more uncertainty the teachers feel about it.

Moreover, for mentoring and instructional support as a practice of the school heads/master teachers, only content knowledge and pedagogical skills ( $\mathrm{r}=.194)$ at 0.01 level of significance has high significant relationships while the remaining indicators have no significant relationship.

It implies that mentoring and instructional support practices of SH/MT affect teacher's competence in delivering conceptual approach, relational understanding, and adaptive reasoning of subject matter. At present, there is a need for school leaders to conduct mentoring and provide instructional support to teachers because they are still embracing the changes in the manner of delivering the lesson to the learners. Therefore, mentoring them influences them to further improve in terms of content knowledge and pedagogical skills. Table 5 presents the test of prediction on the influence of SH and MT practices singly or in combination with teacher's competencies.

Table 5. Test of Prediction on the Influence of SH and MT Practices to Teacher's Competencies

\begin{tabular}{|c|c|c|c|c|c|c|}
\hline \multirow[t]{2}{*}{ Step } & \multirow[t]{2}{*}{ Predictors } & \multicolumn{2}{|c|}{$\begin{array}{l}\text { Unstandardized } \\
\text { Coefficients }\end{array}$} & $\begin{array}{c}\text { Standardized } \\
\text { Coefficients }\end{array}$ & \multirow[t]{2}{*}{$\mathrm{t}$-value } & \multirow[t]{2}{*}{$\begin{array}{c}\mathrm{p}- \\
\text { value }\end{array}$} \\
\hline & & B & Std. Error & Beta & & \\
\hline 1 & $\begin{array}{l}\text { Constant } \\
\text { Staff Development }\end{array}$ & $\begin{array}{l}2.473 \\
.235\end{array}$ & $\begin{array}{l}.221 \\
.061\end{array}$ & .230 & $\begin{array}{l}11.169 \\
3.846\end{array}$ & $\begin{array}{l}.000 \\
.000\end{array}$ \\
\hline 2 & $\begin{array}{l}\text { Constant } \\
\text { Staff Development } \\
\text { Curriculum } \\
\text { Development }\end{array}$ & $\begin{array}{l}.2 .634 \\
.293 \\
-.113\end{array}$ & $\begin{array}{l}.220 \\
.062 \\
.030\end{array}$ & $\begin{array}{r}.286 \\
-.228\end{array}$ & $\begin{array}{r}11.963 \\
4.750 \\
-3.791\end{array}$ & $\begin{array}{l}.000 \\
.000 \\
.000\end{array}$ \\
\hline
\end{tabular}


International Journal of Theory and Application in Elementary and Secondary School Education (IJTAESE), Vol. 3 (2), 125-139

The Relationship of the Strategies and Practices of the School Heads and Master Teachers and Teachers' Competencies and Skills in the New Normal

Noruel M. Donato

A two-step hierarchical stepwise multiple regression tests were employed to determine which among the four (4) important practices of SH/MT influence teacher's competencies. Since only the 'staff development' and 'curriculum development' were among those who exhibited a significant relationship with the independent variable, the summarized data of staff development was entered in step one of the regression procedure and curriculum development followed suit in step two.

The regression estimate procedure revealed that the 'staff development at step one significantly contributed to the model where $F(1,265)=14.790 ; \mathrm{p}<.01$, and explained 5.30 percent of the variance in teacher's competencies. It appears here that the staff development as one of the identified practices of SH/MT provides moderate influence for the teacher to perform at their best. Considering the regression coefficient in Table 2, it can now be claimed that an increase of 1 point in teacher's appreciation of the SH/MT initiative for staff development will be resulted in an average increase of at least twenty-three tenths (.235) of a point on the 5-point teacher competency scale.

The impact of the curriculum development as the predicting variable entered step two is less certain. Though these two variables were included in the stepwise solution, the curriculum development had a reversed sign (-.113) in the model, which in a way will represent a result contrary to the current practices used by the SH/MT. The explained variance of the curriculum development as one of the predicting variables was only .004 out of an overall model R2 of .053.

It implies that the curriculum development practices of MT and SH do not predict what might be the performance of the teachers. It does not give a guarantee that if school leaders properly implement curriculum development practices, it will improve the competencies of the teachers. As a result, the researcher should consider reducing the influence allotted to curriculum development and even possibly omit them from consideration as influences on teacher competencies.

The article was written in the blog "trenducation" (2019) may support the researcher's findings and claim. Curriculum development may not predict the performance and competence of teachers because it is more on the implementation of different types of strategies and methods by which its ultimate goal is on students' achievements and outcomes.

Similarly, Bayrakci and Karacaoglu (2020) presented in their study one feature of curriculum developments. Their study stipulated that curriculum development can identify possible learning outcomes to make appropriate programs for students.

These presented pieces of literature served as evidence that curriculum development does not directly affect teachers' competencies because curriculum development aims to improve learners' achievement.

This study proposes a Learning and Development Program that would help sustain and improve further the competencies and skills of teachers in the new normal. This program highlighted the three learning competencies that somehow do not appear to be related to some of the school heads and master teachers' practices but seem necessary in the new normal.

\section{CONCLUSION}

The said new normal in education does not only pertain to the delivery of learning to the students, but it also changes the monitoring and supervision strategies and practices of school leaders. In this time, teachers' competencies and skills were also glazed with different challenges brought by the present pandemic. Teachers need to adapt to the said new normal and must adopt the different learning delivery modalities presented by the Department of Education. However, teachers' competencies and skills still manifest Highly Proficient, considering the present situation. Thus, teachers' recognition and collaboration with the monitoring and supervisory strategies and practices of the School Heads and Master Teachers considered to be Highly Observed.

Likewise, these imply that the strategies and practices implemented by the SH/MT have a significant relationship to teachers' competencies and skills. That the methods, processes, form, or procedures utilized by school heads and master teachers at schools, produced the mechanism for any educational achievement and professional attainment. Moreover, it denotes that the proper strategies implemented has significant relationship to the practices employed by the SH/MT. It explains that if they effectively and efficiently performed the different ways in implementing the activities aligned to the stipulated practices, it will be 
manifested in their actions on providing proper instructional support to the development of the competencies and skills of the teachers. Finally, it is concluded that staff development implemented by the $\mathrm{SH} / \mathrm{MT}$, moderately influences teachers' competencies and skills. It signifies that they are giving the proper advancements to teachers; however, these advancements might be limited and do not completely address the needs of the teachers in this new normal considering the present distance learning implemented.

In light of these conclusions, school heads and master teachers may continuously attend professional development activities offered by the Division, Region, and Central office to further improve some of their strategies and practices in monitoring and supervising teachers and to acquire strategies that are applicable and appropriate to the new normal. Teachers, Master Teachers, and School Heads are encouraged to pursue graduate or post-graduate studies and may attend professional learning activities to further improve their competencies and widen their professional network. Additionally, the school may offer and conduct activities that may improve and sustain the competencies and skills of teachers. The school may implement activities that may cater to the needs of the teachers, especially on the strategies and technology-aided materials and applications that can be used in teaching in distance learning. The division office may conduct and implement programs that may further improve the skills of school heads and master teachers in monitoring and supervising teachers in the new normal, particularly on instructional supervision, staff development, curriculum development, and mentoring and instructional supports for teachers. Likewise, the school officials may validate or may adopt the developed Learning and Development Program developed by the researcher before its implementation.

\section{REFERENCES}

Aseltine, M. J., Faryniarz, J. O. and Rigazio-Digilio, A. J. (2016). Supervision for earning: A Performancebased Approach to Teacher Development and School Improvement. Virginia: Association for Supervision and Curriculum Development.

Binauhan, Rochelle C. (2019). Learning Action Cell Implementation in The Public Elementary Schools In The Division Of Cavite. International Journal of Advanced Research and Publications. Volume 3 Issue 11

Bayrakcl, Mustafa \& Karacaoğlu,,Ömer Cem (2020). Determination of learning outcomes of curriculum development in education according to questions in KPSS (public personnel selection examination) educational sciences test. International Journal of Curriculum and Instruction. Vol. 12(2), pp 507-532

Burns,Mary. (2015). Distance Education for Teacher Training: Modes, Models and Methods. Education Development Ceter, Inc. Washington, DC.

Canon, Crisostomo B. (2015), Level of Awareness among Grades 7 and 8 Teachers and the Level of Support of DepEd Calamba City to Outcomes-Based Education (OBE) Approach (Unpublished Master's Thesis, Laguna College of Business and Arts).

Chikere, Cornell C. \& Nwoka, Jude (2015). The Systems Theory of Management in Modern Day Organizations - A Study of Aldgate CongressResort Limited Port Harcourt. International Journal of Scientific and Research Publications, Volume 5, Issue 9.

DepEd Order No. 12, s. 2020. Adoption of the Basic Education Learning Continuity Plan for School Year 2020-2021 in Light of the COVID-19 Public Health Emergency.

DepEd Memorandum No. 50, s. 2020. DepEd Professional Development for Teachers and School Leaders for School Year 2020-2023.

Department of Education (2020). Instructional Supervision: Standards, Procedures and Tools. Basic Education Sector Reform Agenda, Teacher Education and Development.

Dolorosa, Rodrigo S. (2020). Administrators' Performance in Compliance with the Standards for Instructional Supervision in the National Capital Region: Basis for Enhanced Supervisory Plan. International Journal of Creative Research Thoughts (IJCRT). Volume 8, Issue 7, ISSN: 2320-2882 
International Journal of Theory and Application in Elementary and Secondary School Education (IJTAESE), Vol. 3 (2), 125-139

The Relationship of the Strategies and Practices of the School Heads and Master Teachers and Teachers' Competencies and Skills in the New Normal

Noruel M. Donato

Ekyaw, BA. (2014) The Practices and Challenges of Instructional Supervision in AsossaZone Primary Schools, Jimma University of Education and Professional development Studies of Educational Planning and Management, Jimma Ethiopia. Retrieved from: http://my.spc.edu.ph:70/e

Ertmer, P.A., Ottenbreit-Leftwich, A., Sadik, O., Sendurur, E., \& Sendurur, P. (2012). Teacher Beliefs and

Technology Integration Practices: A Critical Relationship. Computers \& Education, 59, 423-435.

Ghavifekr, Simin \& Rosdy, Wan Athirah Wan (2015). Teaching and Learning with Technology: Effectiveness of ICT Integration in Schools. International Journal of Research in Education and Science. Volume 1, Issue 2, Summer 2015 ISSN: 2148-9955..

Glanz, J. (2020). Paradigm Debates in Curriculum and Supervision: Modern and Postmodern Perspectives. Westport, CT: Bergin and Garvey.

Glickman, C. D; Gordon, S. P., and Ross-Cordon. 2020. Supervision of Instruction: A Developmental Approach. (4th ed.). Boston, MA: Allyn \& Bacon.

Gumban, Herchel (2019). School-Based Learning Action Cell (SLAC) Activities: A Tool to Enhance Work Performance of Teachers in Norala Districts. Mindanao State University Graduate School

Hero, Jesson L. (2020). Level Shifting, Workload, School Location, Teacher Competency and Principal Leadership Skills in Public Elementary Schools. International Journal of Academic Pedagogical Research (IJAPR), Vol. 4 Issue 7, July - 2020, Pages: 8-13.

Holloway, E. (1995). Clinical supervision: A systems approach. Thousand Oaks, CA: Sage

Iroegbu \& Eyo (2016). Principals' Instructional Supervision and Teachers' Effectiveness. British Journal of Education. Vol.4, No.7, pp.99-109

Johnson, A. M., Jacovina, M. E., Russell, D. E., \& Soto, C. M. (2016). Challenges and Solutions When Using Technologies in the Classroom. In S. A. Crossley \& D. S. McNamara (Eds.) Adaptive Educational Technologies for Literacy Instruction (pp.13-29). New York: Taylor \& Francis. Published with acknowledgment of federal support.

Laska, Lon (2016). Monitoring and Evaluating the Performance of Teachers Through the Process of Observation in the Classroom. European Journal of Multidisciplinary Studies. Vol.1 No. 2.

Lewis, L., \& Parsad, B. (2008). Distance education at degree-granting postsecondary institutions:200607 (NCES 2009-044). Washington: Retrieved from http://nces.ed.gov/pubs2009/2009044.pdfInstitute Lewis, Mitzi (2007). Step versus Hierarchical Regression: Pros and Cons. University of North Texas. Litman, Todd (2020). Planning Principles and Practices. Victoria Transport Policy Institute

Mojavezi, Ahmad and Tamiz, Marzieh Poodineh (2012). The Impact of Teacher Self-efficacy on the Students' Motivation and Achievement. Theory and Practice in Language Studies, Vol. 2, No. 3, pp. 483-491.

Murthy, P. 2020. In the New Vision, July 2020.

Ornstein, A. C., \& Hunkins, F. P. (2012). Curriculum: Foundations, principles, and issues (6th ed.). Boston, MA: Pearson.

Peklaj, Cirila (2015). Teacher Competencies Through the Prism of Educational Research. CEPS Journal. Vol.5. No 3.

Prytula, M. \& K. Weiman, (2012) “Collaborative professional development: An examination of changes in changes in teacher identity through the professional learning community model. "Journal of Case Studies in Education 3 (Jul 2012): 1-19, 2012.

Puteh, Marzita (2016). Effective Teaching: Pedagogical Content Knowledge. Universiti Pendidikan Sultan Idris (UPSI). Retrieved January 07, 2021, from https://www.researchgate.net

Saxena R., Saxena S.K. (2020). Preparing Children for Pandemics. In: Saxena S. (eds) Coronavirus Disease 2019 (COVID-19). Medical Virology: From Pathogenesis to Disease Control. Springer, Singapore. https://doi.org/10.1007/978-981-15-4814- 7_15 
Smith, Kendra (2009). A Brief Summary of Supervision Models. Retrieved. January 05, 2021, from https://www.marquette.edu

Sullivan, S. and Glanz, J. 2020. Supervision the Improves Teaching: Strategies and Techniques. Thousands Oaks, CA: Corwin Press, Inc.

Tarek, S. (2016). Distance Learning: The Role of the Teacher, Available online at www.docuri.com, Date Accessed, 15 August 2015Thach, E.C., Murphy, K.L.(1995). Competencies for Distance Education Professionals. ETR\&D 43, 57-79 (1995). https://doi.org/10.1007/Bf02300482

Tuscano, F. (2020). It's not about Online Learning: A Reflection on the "New Normal" in Education, Available online at www.francisjimtuscano.com, Date Accessed 16 August 2020

Zepeda, S. J. 2020. Instructional Supervision: Applying Tools and Concepts. Larchmont, NY: Eye on Education. 